\title{
Phytochemical and Biological Studies of Some Myrtus (Myrtus communis L.) Populations of South West Region of Zagros (Iran)
}

Alireza Salimi Beni ${ }^{1^{*}}$, Mehrzad Kocheki Shahmokhtar ${ }^{1}$, Asad MasoumiasI $^{2}$ and Habibollah Khajehsharifi ${ }^{1}$

${ }^{1}$ Department of Chemistry, Yasuj University, Yasuj, Iran

${ }^{2}$ Agricultural Department, Yasuj University, Yasuj, Iran

"Corresponding author: Salimi Beni A, Department of Chemistry, Yasuj University, Yasuj, Iran, Tel: +987431004000; E-mail: alirezasalimi7173291@gmail.com

Received: August 12, 2017; Accepted: August 21, 2017; Published: August 30, 2017

Copyright: (c) 2017 Salimi Beni A, et al. This is an open-access article distributed under the terms of the Creative Commons Attribution License, which permits unrestricted use, distribution, and reproduction in any medium, provided the original author and source are credited.

\begin{abstract}
Myrtus communis $L$. is one member of the Myrtaceae family. It is one of the important medicinal plants in the Zagros region of Iran. The Essential oils include a large percentage of compounds called terpenes. In this study, the chemical composition of essential oils of Myrtus (Myrtus communis L.) was identified by the GC-MS method. Results showed that essential oils of populations from different regions have a series of similar compounds, but different in quality and quantity. In fact, they have several organic compounds such as hydrocarbons, alcohols, ketones, aldehydes, ethers, esters, oxides and other volatile oil and so on. Percentage of essential oils in different populations were variable. Essential oil of "Basht" population has 35 compounds such as 1,8-cineole, linalool, $\alpha-$ pinene and lynalyl acetate. Essential oils of "Dehno-Rostam" population has 30 compounds include 1, 8 cineole, linalool, $\alpha$ terpineol, $\alpha$-pinene. Essential oils of "Sarab-Bahram" population has 19 compounds include $\alpha$-pinene, 1,8cineole, linalool, and $\alpha$ terpineol. Essential oils of "Keveshk" population has 29 compounds such as 1,8-cineole, $\alpha$ pinene, linalool, and a-terpineol and Essential oils of "Tang-Tamoradi" population has 25 compounds include Eugenol, $\delta$-3-carene, 1,8-cineole, and a-terpineol. Aqueous extracts of those populations were evaluated, and the results showed that they have antibacterial properties against Escherichia coli, Bacillus subtilis and Pseudomonas aeruginosa, but have not any antifungal activity (Aspergillus oryzae).
\end{abstract}

Keywords: Myrtus communis L.; Zagros; Essential oil; Antimicrobial; Antifungal

\section{Introduction}

Myrtus communis L. (Myrtaceae) is an evergreen shrub, typical of the Mediterranean regions, which grows spontaneously in many countries, the scientific name for this Myrtus communis $L$. is taken from its Persian name. It is traditionally used as an antiseptic, antimicrobial, disinfectant drug and hypoglycaemic agent [1]. Different parts of this plant find various widely uses in the food industry, such as for flavouring meat and sauces, and in the cosmetic industry and so on [2]. Common myrtle belongs to the Myrtaceae family, which include approximately 145 genera and over 5500 species [3]. The genus Myrtus includes the flowering plant with near 16 species reported in areas of the Middle East and Asia [4]. M. communis $L$. known in fact myrtle is one of the main aromatic and medicinal species of this family. It is an evergreen sclerophyll shrub or small tree, 1.8-2.5 m height, with a small bush and deeply fissured grove [5]. True Myrtle is characterized by its branches, which form a close full head, gross covered with ovate or lanceolate evergreen leaves. Their leaves are $3-5 \mathrm{~cm}$ long and include tannins, flavonoids and volatile oils [6]. This part is a so aromatic plant since of the high essential oil content in its leaf, flower and fruit glands. It has solitary auxiliaries white or rosy flowers followed by black a several-seeded berry, which is globular in shape with dark red to violet in color [7]. There are two major fruits according to whether the color dark or white. The dark color is more current, but there are as well cultivated white-colored types, which they have yielded much bigger fruit than their wild counterparts [8]. Myrtle grows abundantly from the northwestern to the eastern Mediterranean, including bordering countries and western Asia, also
Aegean regions [9]. Myrtles native to Southern Europe, North Africa and western Asia. It is also distributed in Southern America, Northwestern Himalaya and Australia. Myrtle is cultivated in gardens, especially in the Northwest Indian region, because of its odor flowers [10]. Myrtle has been used since ancient times as a spice, also for medicinal, antiseptic, food preparation and spice purposes. Myrtle as a condiment finds no wide application because of its bitterness, despite the pleasant odor. The taste is very intense, quite nasty and strongly bitter, so its culinary application is limited to the region of origin, such as Italy $[11,12]$. Its berries and leaves are usually used for the industrial formulation of sweet liquors with advertising digestive properties $[13,14]$. Its leaves are very fragrant and have been extensively employed in the perfume and cosmetic industries, particularly in Portugal [15] and Turkey [6]. It is traditionally used as an antiseptic, disinfectant and hypoglycemic agent [1]. Generally, in folk medicine, a decoction of leaves and fruits is used orally for the treatment of stomach aches, hypoglycaemia, disbiosis, cough, constipation, poor appetite, as well as also externally for wound healing [16]. Essential oils are aromatic and volatile compounds found only in $11 \%$ of the plant kingdom [17]. Essential oils and their components can be very hopeful biological agents, to their relative safety, wide acceptation by consumers and exploitation of potential multi-purpose use [18]. They are stored in plants in special fragile secretory structures, such as glands, secretory hairs, secretory ducts, secretory pit or resin ducts [19-22]. The total essential oil content of plants is generally so low and scarcely more than $1 \%$ of biomass [23]. For example, the essential oil yields in leaf stalk and flower of $M$. communis var. Italical were respectively $0.61 \%$, $0.08 \%$ and $0.30 \%(\mathrm{w} / \mathrm{w})$ [24]. Essential oils are hydrophobic and thus only slightly solvable in water. They are soluble in alcohol, non-polar or weakly polar solvents, beeswax, and oils. Most essential oils are colorless or light yellow, liquid and have a lower density than water 
Page 2 of 6

[25]. Essential oils are complex mixtures containing many diverse compounds. Chemically they are derived from terpenes and their oxygenated compounds [26]. The chemical composition of the myrtle essential oil has been explained by many authors [2,27-29]. Compounds that have been found in myrtle oils include E-2-hexenal, Z-3-hexenol, hexanol, tricyclene, $\alpha$-thujene, $\alpha$-pinene, sabinene, $\beta$ pinene, myrcene, $\delta$-3-carene, $\alpha$-terpinene, p-cymene, limonene, 1,8 cineole, E- $\beta$-ocimene, E-oxide, terpinolene, linalool, terpinene-4-ol, borneol, p-cymene-8-ol, a-terpineol, myrtenol, nerol, cis-carveol, geraniol, linalylacetate, bornyl acetate, eugenol, myrtenyl acetate, $\alpha$ terpinyl acetate, geranyl acetate, neryl acetate, methyl eugenol, $\beta$ caryophyllene, $\alpha$-humulene, allo-aromadendrene, germacrene- $D$, caryophyllene oxide and camphene.

\section{Materials and Methods}

\section{Plant material and essential oil}

In June with the use of plant distribution maps for Myrtus communis $L$. five regions for sampling was selected. The different geographical characteristics of these regions were measured. Latitude, longitude and altitude to the global coordinate system (GPS) were measured (Table 1). Then samples (leaf and twigs) were dried away from the sun for ten days. Dried leaves transferred to the Phyto chemistry Laboratory and extraction essential oils by Clevenger for 3 hours. Finally, essential oils after dehydration kept in the dark glass bottle in the refrigerator (in $4^{\circ} \mathrm{C}$ ). Percentage of essential oils in this studied population were shown in Table 2 .

\begin{tabular}{|l|l|l|l|l|}
\hline Row & Name of Location & Altitude $(\mathbf{m})$ & Latitude & Longitude \\
\hline 1 & Basht & 930 & 302029 & 511142 \\
\hline 2 & Dehno Rostam & 810 & 301854 & 512158 \\
\hline 3 & Sar Ab Bahram & 1037 & 300229 & 513330 \\
\hline 4 & Keveshk & 1712 & 302650 & 512916 \\
\hline 5 & Tang Tamoradi & 1623 & 303048 & 512509 \\
\hline
\end{tabular}

Table 1: Geographical characteristics of studied regions.

\begin{tabular}{|l|l|}
\hline Name of Location & Percentage of essential oils \\
\hline Basht & 2.2 \\
\hline Dehno-Rostam & 2.1 \\
\hline Sarab-Bahram & 1.6 \\
\hline Keveshk & 2.0 \\
\hline Tang-Tamoradi & 0.8 \\
\hline
\end{tabular}

Table 2: Percentage of essential oils in studied populations.

\section{Preparation of the extracts}

The aqueous extract was obtained as follows: $80 \mathrm{ml}$ of water added in $10 \mathrm{~g}$ of plant material in a round-bottomed flask, then put it on the electric mixer for $24 \mathrm{~h}$. Then it was a smooth operation and filtered by Whatman paper No. 42 .

\section{Preparation of the culture medium}

Based on the directions on the container culture media, culture media powder is dissolved in distilled water and heater stirred until the boil, Then the flask door closed with cotton for $20 \mathrm{~min}$ at $121^{\circ} \mathrm{C}$ inside the autoclave to be sterilized. After leaving autoclave poured about 15 $\mathrm{ml}$ of culture medium in each plate after cooling to keep in the refrigerator. Broth as the liquid culture medium is not necessary to pour plates can be directly stored in the fridge after sterilization and cooling.

\section{Analysis of the essential oils}

To determine the composition of the essential oils of the leaves was used gas chromatography and gas chromatography (Agilent, Model N 6890) connected mass spectrometry (GC-MS). HPS column (30 meter), its diameter was 250 micrometers and thickness of stationary phase $0.25 \mathrm{~m}$. Helium was used as the carrier gas at a flow rate of 1.0 $\mathrm{ml} / \mathrm{min}$. Diluted samples (1/100 in $\mathrm{n}-\mathrm{Hexan}, \mathrm{v} / \mathrm{v})$ of $1 \mu \mathrm{l}$ were injected manually in split mode (split ratio 1/30). Oven temperature was programmed from 50 to $220^{\circ} \mathrm{C}$ at a rate of $5^{\circ} \mathrm{C} / \mathrm{min}$ and from $220^{\circ} \mathrm{C}$ to $280^{\circ} \mathrm{C}$ at a rate $20^{\circ} \mathrm{C} / \mathrm{min}$ and held at for $2 \mathrm{~min}$. Oil constituents were identified by MS data obtained from Wiley (http://eu.wiley. com/ wileycad/wileyTitle/productCd.htm) and NIST (http:// www.nist.gov/srd/nistla.htm) libraries.

\section{Biological activity}

In-vitro biological activity of the extracts against two Gram negative bacteria such as Escherichia coli (ATCC 25922) and Pseudomonas aeroginosa (ATCC 9027) and Gram-positive bacteria including $S$. Bacillus subtilis (ATCC: 6633 ) and also a fungal strain such as $A$. oryzae, were carried out using the disk diffusion method [30,31]. For this mean, the Petri dishes were prepared as follows: i) a layer of culture medium (Muller Hinton Agar (Merck, Germany) for bacterial strains and Sabouraud dextrose agar (SDA) for fungal strains was poured on the surface of plates, ii) $100 \mu \mathrm{l}$ of spore suspension of bacteria and/or fungi including nearly $0.5 \times 106$ colony-forming units $(\mathrm{CFU} / \mathrm{ml})$ was inoculated on the surface of culture medium, iii) The prepared discs (that had been soaked in the various concentrations of Extracts; $12.5,25$ and $50 \mathrm{mg} / \mathrm{ml}$ in physiological saline) were placed at different positions on a surface of plates. Then, the plates were incubated at $37^{\circ} \mathrm{C}$ for $24 \mathrm{~h}$ for bacterial strains and $27^{\circ} \mathrm{C}$ for three days for Aspergillus oryzae [32,33]. Antimicrobial activities of extracts were evaluated based on the diameter of the zone of inhibition $(\mathrm{mm})$ and listed in Table 8. Amoxicillin, Erythromycin, Fluoxamine and Cephalexin were used as reference bactericidal drugs (positive controls) Table 9.

\section{Results and Discussion}

The geographical characteristics of the study regions (latitude, longitude and altitude) were shown in Table 1. Essential oil extraction by Clevenger and dehydration by $\mathrm{Na}_{2} \mathrm{SO}_{4}$ then compounds in essential oils were identified by chromatography connected to mass spectrometry (GC-MS). Chemical compounds were identified in different populations was shown in Tables 3-7. In the essential oil of Basht population was identified 35 compounds and 1,8-cineole, linalool, a-pinene and lynalyl acetate have the highest percent (Table 3).

\begin{tabular}{|l|l|l|l|}
\hline Row & Compounds name & Retention time (min) & Percent \\
\hline
\end{tabular}


Citation: Salimi Beni A, Kocheki Shahmokhtar MK, Masoumias A, Khajehsharifi H (2017) Phytochemical and Biological Studies of Some Myrtus (Myrtus communis L.) Populations of South West Region of Zagros (Iran) . Nat Prod Chem Res 5: 290. doi:10.4172/2329-6836.1000290

Page 3 of 6

\begin{tabular}{|c|c|c|c|}
\hline 1 & Isobutyl isobutyrate & 3.855 & 1.48 \\
\hline 2 & a-Pinene & 4.288 & 7.98 \\
\hline 3 & Camphene & 5.171 & 4.12 \\
\hline 4 & $\delta$-3-carene & 5.347 & 2.73 \\
\hline 5 & P-cymene & 5.586 & 3.56 \\
\hline 6 & Unknown & 5.864 & 1.30 \\
\hline 7 & 1,8 -cineol & 6.355 & 12.89 \\
\hline 8 & Ocimene & 7.241 & 0.78 \\
\hline 9 & $\mathrm{y}$-terpinene & 7.330 & 0.53 \\
\hline 10 & Linalool oxide & 7.510 & 0.25 \\
\hline 11 & a-terpinolene & 7.825 & 0.33 \\
\hline 12 & Linalool & 8.214 & 12.10 \\
\hline 13 & Allo ocimene & 8.933 & 0.30 \\
\hline 14 & Trans-pinocarveol & 9.305 & 0.39 \\
\hline 15 & Cis-verbinol & 9.378 & 0.45 \\
\hline 16 & Unknown & 9.585 & 0.44 \\
\hline 17 & Borneol & 9.962 & 0.11 \\
\hline 18 & 4-terpineol & 10.213 & 0.70 \\
\hline 19 & A-terpineol & 10.618 & 4.43 \\
\hline 20 & Unknown & 10.699 & 1.52 \\
\hline 21 & Myrtenal & 10.866 & 6.24 \\
\hline 22 & Trans-geraniol & 11.568 & 0.68 \\
\hline 23 & Citronellol & 11.745 & 0.75 \\
\hline 24 & Linalyl acetate & 12.381 & 7.73 \\
\hline 25 & Bornyl acetate & 13.088 & 0.24 \\
\hline 26 & Myrtenyl acetate & 13.834 & 0.05 \\
\hline 27 & $\alpha$-terpenyl acetate & 14.909 & 6.15 \\
\hline 28 & Neryl acetate & 15.073 & 0.95 \\
\hline 29 & Granyl acetate & 15.218 & 0.17 \\
\hline 30 & Terpinyl propionate & 15.743 & 4.50 \\
\hline 31 & Methyl eugenol & 16.380 & 2.55 \\
\hline 32 & Trans-Caryophellene & 16.864 & 2.08 \\
\hline 33 & $\alpha$-Humulene & 17.669 & 1.90 \\
\hline 34 & Caryo phellene oxide & 20.952 & 2.15 \\
\hline 35 & Humulene oxide (II) & 21.570 & 1.12 \\
\hline
\end{tabular}

Sarab-Bahram population was identified 19 compounds and $\alpha$-pinene, 1,8-cineole, linalool, and $\alpha$ terpineol have the highest percent (Table 5). Keveshk population has 29 compounds and 1,8-cineole, a-pinene, linalool, and $\alpha$-terpineol have the highest percent (Table 6). TangTamoradi population has 25 compounds and Eugenol, $\delta$-3-carene, 1,8cineole, and a-terpineol have the highest percent (Table 7). The antibacterial activities of the extracts were listed in Table 8 as the diameter of inhibition zone from the growth (in $\mathrm{mm}$ ). The results show that extracts have the good antibacterial activity against all studied bacteria strains. Antibacterial activities of Basht, Dehno-Rostam, Sarab-Bahram and Keveshk populations was similar and have most effect on Pseudomonas aeruginosa, Escherichia coli and Bacillus subtilis, respectively. Antibacterial activity Tangeh-tamoradi population has different and has the greatest effect on the Pseudomonas aeruginosa, Bacillus subtilis and Escherichia coli, respectively. Antibacterial activity of Amoxicillin, Erythromycin, Fluoxamine and Cephalexin were (positive controls) shown in Table 9. The Aqueous extracts of those populations have not any antifungal activity against Aspergillus oryzae.

\begin{tabular}{|c|c|c|c|}
\hline Row & Compounds name & Retention time (min) & Percent \\
\hline 1 & Isobutyl isobutyrate & 3.770 & 2.4 \\
\hline 2 & Unknown & 4.031 & 1.00 \\
\hline 3 & a-Pinene & 4.233 & 10.32 \\
\hline 4 & $\beta$-Pinene & 4.861 & 3.72 \\
\hline 5 & $\delta$-3-careen & 4.984 & 4.20 \\
\hline 6 & Unknown & 5.206 & 2.70 \\
\hline 7 & T- $\beta$-Ocimene & 5.315 & 2.82 \\
\hline 8 & P-cymene & 5.561 & 6.80 \\
\hline 9 & 1,8-cineol & 6.315 & 16.02 \\
\hline 10 & cis- $\beta$-Ocimene & 6.962 & 2.40 \\
\hline 11 & $\mathrm{y}$-terpinene & 7.114 & 2.32 \\
\hline 12 & a-terpinolene & 7.710 & 1.25 \\
\hline 13 & Linalool & 8.161 & 14.54 \\
\hline 14 & Allo ocimene & 8.826 & 0.62 \\
\hline 15 & Trans-pinocarveol & 9.174 & 0.60 \\
\hline 16 & Undecane,5-methyl & 9.305 & 0.72 \\
\hline 17 & Iso Borneol & 9.768 & 0.56 \\
\hline 18 & 4-terpineol & 10.068 & 0.73 \\
\hline 19 & a-terpineol & 10.744 & 11.10 \\
\hline 20 & trans-(+)-carveol & 11.160 & 0.40 \\
\hline 21 & Trans-geraniol & 11.470 & 1.11 \\
\hline 22 & Linalyl acetate & 12.160 & 7.60 \\
\hline 23 & a-citral & 12.496 & 0.16 \\
\hline 24 & Myrtenalacetate & 13.824 & 1.11 \\
\hline 25 & Methyl granate & 13.948 & 0.48 \\
\hline
\end{tabular}

The dehno-Rostam population has 30 compounds and 1,8-cineole, linalool, a terpineol, a-pinene have the highest percent (Table 4). In 
Citation: Salimi Beni A, Kocheki Shahmokhtar MK, Masoumias A, Khajehsharifi H (2017) Phytochemical and Biological Studies of Some Myrtus (Myrtus communis L.) Populations of South West Region of Zagros (Iran) . Nat Prod Chem Res 5: 290. doi:10.4172/2329-6836.1000290

Page 4 of 6

\begin{tabular}{|l|l|l|l|}
\hline 26 & Neryl acetate & 14.970 & 1.70 \\
\hline 27 & Methyl eugenol & 16.294 & 0.08 \\
\hline 28 & Trans-Caryophellene & 16.634 & 0.80 \\
\hline 29 & a-Humulene & 17.481 & 0.91 \\
\hline 30 & Caryo phellene oxide & 20.782 & 0.83 \\
\hline
\end{tabular}

Table 4: Compounds in essential oils of Dehno-Rostam population.

\begin{tabular}{|c|c|c|c|}
\hline Row & Compounds name & Retention time (min) & Percent \\
\hline 1 & a-Pinene & 4.515 & 33.9 \\
\hline 2 & P-cymene & 5.581 & 9.22 \\
\hline 3 & 1,8-cineol & 6.415 & 22.1 \\
\hline 4 & a-terpinolene & 7.623 & 1.3 \\
\hline 5 & Linalool & 7.966 & 11.92 \\
\hline 6 & Undecane,5-methyl & 8.559 & 1.23 \\
\hline 7 & Iso Borneol & 9.630 & 1.21 \\
\hline 8 & 4-terpineol & 9.927 & 1.2 \\
\hline 9 & a-terpineol & 10.324 & 3.92 \\
\hline 10 & Nerol & 11.184 & 1.05 \\
\hline 11 & Linalyl acetate & 11.930 & 2.82 \\
\hline 12 & Trans anethole & 12.779 & 1.03 \\
\hline 13 & Methyl granat & 13.707 & 0.92 \\
\hline 14 & Myrtenel acetate & 13.835 & 1.05 \\
\hline 15 & Methyl eugenol & 15.879 & 1.9 \\
\hline 16 & Trans-Caryophellene & 16.497 & 1.2 \\
\hline 17 & a-Humulene & 17.375 & 1.12 \\
\hline 18 & Caryo phellene oxide & 20.726 & 1.46 \\
\hline 19 & Humulene oxide (II) & 21.30 & 1.45 \\
\hline
\end{tabular}

Table 5: Compounds in essential oils Sarab-Bahram population.

\begin{tabular}{|l|l|l|l|}
\hline Row & Compounds name & Retention time $(\mathbf{m i n})$ & Percent \\
\hline 1 & Iso butyl iso butyrate & 3.912 & 2.34 \\
\hline 2 & $\alpha-P i n e n e$ & 4.365 & 13.2 \\
\hline 3 & $\beta$-Pinene & 4.869 & 6.32 \\
\hline 4 & pseudo limonene & 5.079 & 6.28 \\
\hline 5 & ס-3-careen & 5.279 & 2.6 \\
\hline 6 & Unknown & 6.019 & 2.61 \\
\hline 7 & $1,8-c i n e o l$ & 6.393 & 15.21 \\
\hline 8 & $\beta$-Ocimene & 6.748 & 3.12 \\
\hline
\end{tabular}

\begin{tabular}{|c|c|c|c|}
\hline 9 & $\mathrm{y}$-terpinene & 6.986 & 2.72 \\
\hline 10 & a-terpinolene & 7.647 & 1.2 \\
\hline 11 & Linalool & 8.088 & 1.8 \\
\hline 12 & Allo ocimene & 8.645 & 1.42 \\
\hline 13 & Unknown & 8.919 & 1.02 \\
\hline 14 & Trans-pinocarveol & 9.025 & 1.14 \\
\hline 15 & Undecane,5-methyl & 9.203 & 1.31 \\
\hline 16 & 4-terpineol & 9.950 & 0.7 \\
\hline 17 & a-terpineol & 10.404 & 12.23 \\
\hline 18 & Linalyl acetate & 12.079 & 9.94 \\
\hline 19 & Trans anethole & 12.811 & 1.0 \\
\hline 20 & Myrtenal acetate & 13.850 & 1.23 \\
\hline 21 & Neryl acetate & 14.818 & 1.31 \\
\hline 22 & Unknown & 14.934 & 0.88 \\
\hline 23 & Granyl acetate & 15.407 & 2.9 \\
\hline 24 & Unknown & 15.830 & 2.8 \\
\hline 25 & Methyl eugenol & 15.953 & 0.91 \\
\hline 26 & Trans-Caryophellene & 16.550 & 0.42 \\
\hline 27 & a-Humulene & 17.413 & 1.4 \\
\hline 28 & Caryo phellene oxide & 20.701 & 1.04 \\
\hline 29 & Humulene oxide (II) & 21.343 & 0.95 \\
\hline
\end{tabular}

Table 6: Compounds in essential oils of Keveshk population.

\begin{tabular}{|c|c|c|c|}
\hline Row & Compounds name & Retention time (min) & Percent \\
\hline 1 & a-Pinene & 4.240 & 3.92 \\
\hline 2 & $\beta$-Pinene & 4.370 & 4.54 \\
\hline 3 & $\delta$-3-careen & 4.856 & 10.96 \\
\hline 4 & $t-\beta$-ocimene & 5.459 & 2.37 \\
\hline 5 & Unknown & 5.606 & 5.53 \\
\hline 6 & Unknown & 6.228 & 2.15 \\
\hline 7 & 1,8-cineol & 6.441 & 10.32 \\
\hline 8 & a-terpinolene & 7.506 & 1.22 \\
\hline 9 & Linalool & 8.039 & 5.56 \\
\hline 10 & Allo ocimene & 8.804 & 0.95 \\
\hline 11 & Camphor & 9.353 & 3.54 \\
\hline 12 & Iso Borneol & 9.960 & 4.51 \\
\hline 13 & a-terpineol & 10.724 & 8.25 \\
\hline 14 & Unknown & 11.152 & 4.43 \\
\hline
\end{tabular}


Citation: Salimi Beni A, Kocheki Shahmokhtar MK, Masoumias A, Khajehsharifi H (2017) Phytochemical and Biological Studies of Some Myrtus (Myrtus communis L.) Populations of South West Region of Zagros (Iran) . Nat Prod Chem Res 5: 290. doi:10.4172/2329-6836.1000290

Page 5 of 6

\begin{tabular}{|l|l|l|l|}
\hline 15 & Linalyl acetate & 12.224 & 7.47 \\
\hline 16 & Bornyl acetate & 12.883 & 0.76 \\
\hline 17 & Myrtenyl acetate & 13.989 & 0.62 \\
\hline 18 & Eugenol & 15.610 & 11.5 \\
\hline 19 & Granyl acetate & 16.28 & 2.04 \\
\hline 20 & Methyl eugenol & 16.430 & 2.93 \\
\hline 21 & Trans-Caryophellene & 16.866 & 2.82 \\
\hline
\end{tabular}

\begin{tabular}{|l|l|l|l|}
\hline 22 & a-Humulene & 17.626 & 0.48 \\
\hline 23 & Caryo phellene oxide & 20.094 & 1.05 \\
\hline 24 & Unknown & 20.899 & 2 \\
\hline 25 & Unknown & 24.437 & 0.08 \\
\hline
\end{tabular}

Table 7: Compounds in essential oils of Tang-Tamoradi population.

\begin{tabular}{|c|c|c|c|c|c|c|c|c|c|}
\hline \multirow{3}{*}{$\begin{array}{l}\text { Name } \\
\text { Location }\end{array}$} & \multicolumn{6}{|c|}{ Gram negative } & \multirow{2}{*}{\multicolumn{3}{|c|}{$\begin{array}{l}\text { Gram positive } \\
\text { Bacillus subtilis }\end{array}$}} \\
\hline & \multicolumn{3}{|c|}{ Escherichia Coli } & \multicolumn{3}{|c|}{ Pseudomons aeruginosa } & & & \\
\hline & $50(\mathrm{mg} / \mathrm{mL})$ & $25(\mathrm{mg} / \mathrm{mL})$ & $12.5(\mathrm{mg} / \mathrm{mL})$ & $50(\mathrm{mg} / \mathrm{mL})$ & $25(\mathrm{mg} / \mathrm{mL})$ & $12.5(\mathrm{mg} / \mathrm{mL})$ & $50(\mathrm{mg} / \mathrm{mL})$ & $25(\mathrm{mg} / \mathrm{mL})$ & $12.5(\mathrm{mg} / \mathrm{mL})$ \\
\hline Basht & 13.72 & 10.10 & 7.66 & 18.76 & 17.53 & 14.53 & 11.48 & 9.77 & 8.46 \\
\hline Dehno-Rostam & 15.14 & 12.48 & 9.80 & 17.88 & 14.64 & 11.88 & 12.85 & 12.41 & 9.30 \\
\hline Sarab-Bahram & 12.99 & 9.65 & 6.88 & 14.06 & 11.53 & 8.38 & 12.45 & 11.51 & 9.00 \\
\hline Keveshk & 13.21 & 9.57 & 6.00 & 15.20 & 11.20 & 9.66 & 13.04 & 9.03 & 6.83 \\
\hline Tang-Tamoradi & 10.80 & 9.73 & 6.00 & 15.49 & 13.07 & 9.28 & 12.21 & 10.66 & 9.03 \\
\hline
\end{tabular}

Table 8: Diameter of zone of inhibition ( $\mathrm{mm}$ ) of extracts in studied populations.

\begin{tabular}{|l|l|l|l|}
\hline Antibiotics & Escherichia Coli & Pseudomonas aeruginosa & Bacillus subtilis \\
\hline Amoxicillin $(30 \mu \mathrm{g})$ & 24.00 & 22.63 & 18.15 \\
\hline Erythromycin $(15 \mu \mathrm{g})$ & 20.33 & 21.27 & 27.44 \\
\hline Fluoxamine $(15 \mu \mathrm{g})$ & 33.33 & 23.11 & 38.37 \\
\hline Cephalexin $(25 \mu \mathrm{g})$ & 19.1 & 15.00 & 35.67 \\
\hline
\end{tabular}

Table 9: Diameter of the zone of inhibition ( $\mathrm{mm}$ ) of Antibiotics.

\section{Conclusion}

This paper deals with the Environmental variation of the essential oil M. communis L. grown in South West region of Zagros. It should be noted that plants from this location are examined for the first time. The monoterpene fraction is the main chemical group of the essential oil in all populations. Essential oils of different populations have a series of compounds are similar and different in terms of quality and quantity. The essential oils are made of a complex mix of chemical compounds that those are different in terms of chemical compounds. In fact, there are a variety of organic compounds such as hydrocarbons, alcohols, ketones, aldehydes, ethers, esters, oxides and other volatile oil and so on. Percentage of essential oil in different regions is different. The results show that extracts have the good antibacterial activity against all studied bacteria strains. Antibacterial activities of Basht, DehnoRostam, Sarab-Bahram and Keveshk populations were similar and have the most effect on Pseudomonas aeruginosa, Escherichia coli and Bacillus subtilis, respectively. The antibacterial activity of the TangehTamoradi population was different and has the greatest effect on the Pseudomonas aeruginosa, Bacillus subtilis and Escherichia coli, respectively. The Aqueous extracts of those populations have not any antifungal activity against Aspergillus oryzae. This study shows that the combination of some Myrtus (Myrtus communis) populations in a different area can vary in terms of quality and quantity that these differences could be due to genetic or non-genetic factors. The result shows the aqueous extracts of Myrtus communis $L$. populations weren't a good alternative for antibiotics. The present results exhort additional and more in-depth studies on the phenolic, fat acid, glucoside and terpenoids composition of the plant extracts and assessment of the antibacterial activity of each compound separately also other biological properties.

\section{Acknowledgment}

This work was carried out with the financial support of Yasouj University (YU).

\section{References}

1. Elfellah MS, Akhter MH, Khan MT (1984) Anti hyperglycaemic effect of an extract of Myrtus communis in streptozotocin-induced diabetes in mice. J Ethnopharmacol 11: 275-281. 
2. Chalchat JC, Garry RF, Michet A (1998) Essential oils of Myrtle (Myrtus communis L.) of the Miterranean littoral. J Essential Oil Res 1998; 10: 613-617.

3. Snow N, McFadden J, Evans TM, Salywon AM, Wojciechowski MF, et al. (2011) Morphological and molecular evidence of polyphyly in rhodo myrtus (Myrtaceae: Myrteae). Syst Bot 36: 390-404.

4. Twaij HA, Ali HM, Al-Zohyri AM (1988) Phytochemical and antimicrobial studies of Myrtus communis. J Biol Sci Res 19: 29-39.

5. Mendes MM, Rodrigues ML (2001) Acclimation of Myrtus communis to contrasting Mediterranean light environments: effects on structure and chemical composition of foliage and plant water relations. Environ Exp Bot 45: 165-178.

6. Baytop T (1999) Therapy with medicinal plants in Turkey (past and present). Istanbul: Nobel Medical Press.

7. Mahmoud IN, El-Sayed AA, Rania FA, Ezzel-Din A, El-Khrisy Khaled MI (2010) Secondary metabolites and bioactivities of Myrtus communis. Pharmacognosy Res 2: 325-329.

8. Klein JD, Cohen S, Hebbe Y (2000) Seasonal variation in rooting ability of myrtle (Myrtus communis L.) cuttings. Sci Hortic 83: 71-76.

9. Baytop T (1997) Turkish Plant Names Dictionary of Gu [Dictionary of Turkish names of plants]. Ankara: Turkish Language Institute Publications, p: 578.

10. Nadkarni KM (1989) Indian materia medica, 838, (3rd edn). Bombay: Popular Prakashan Pvt. Ltd.

11. Cannas S, Molicotti P, Ruggeri M, Cubeddu M, Sanguinetti M, et al. (2013) Antimycotic activity of Myrtus communis L. towards Candida spp. from clinical isolates. J Infect Dev Ctries 7: 295-298.

12. Gortzi O, Lalas S, Chinou I, Tsaknis J (2008) Re-evaluation of bioactivity and antioxidant activity of Myrtus communis extract before and after encapsulation in liposomes. Eur Food Res Technol 226: 583-590.

13. Messaoud C, Laabidi A, Boussaid M (2012) Myrtus communis L. infusions: the effect of infusion time on phytochemical composition, antioxidant and antimicrobial activities. J Food Sci 77: 941-947.

14. Chalchat JC, Garry RF, Michet A (1998) Essential oils of Myrtle (Myrtus communis L.) of the Miterranean littoral. J Essential Oil Res 10: 613-617.

15. Clark AM (1996) Natural products as a resource for new drugs. Pharmaceut Res 13: 1133-1144.

16. Serce S, Ercisli S, Sengul M, Gunduz K, Orhan E (2010) Antioxidant activities and fatty acid composition of wild grown myrtle (Myrtus communis L.) fruits. Pharmacogn Mag 6: 9-12.

17. Djilani A, Dicko A (2012) The therapeutic benefits of essential oils. In: Bouayed J, editor. Nutrition, well-being and health. In Tech, pp: 155-178.

18. Ormancey X, Sisalli S, Coutiere P (2001) Formulation of essential oils in functional par-fumery. Perf Cosm Actua 157:30-40.

19. Ahmadi L, Mirza M, Shahmir F (2002) The volatile constituents of Artemisia marschaliana Sprengel and its secretory elements. Flavour Frag J 17: 141-143.
20. Bezic N, Samanic I, Dunkic V, Besendorfer V, Puizina J (2009) Essential oil composition and internal transcribed spacer (ITS) sequence variability of four south-Croatian Satureja species (Lamiaceae). Molecules 14: 925-938.

21. Ciccarelli D, Garbari F, Pagni AM (2008) The flower of Myrtus communis (Myrtaceae): secretory structures, unicellular papillae, and their ecological role. Flora 203: 85-93.

22. Gershenzon J (1994) Metabolic costs of terpenoid accumulation in higher plants. J Chem Ecol 20: 1281-1290.

23. Bowles EJ (2003) The chemistry of aromatherapeutic oils, (3rd edn) South Australia: Griffin Press.

24. Aidi Wannes WA, Mhamdi B, Sriti J, Jemia MB, Ouchikh O, et al. (2010) Antioxidant activities of the essential oils and methanol extracts from myrtle (Myrtus communis var. italica L.) leaf, stem and flower. Food Chem Toxicol 48: 1362-1370.

25. Gupta V, Mittal P, Bansal P, Khokra SL, Kaushik D (2010) Pharmacological Potential of Matricaria recutita. Int J Pharm Sci Drug Res 2: 121-166.

26. Prabuseenivasan S, Jayakumar M, Ignacimuthu S (2006) In vitro antibacterial activity of some plant essential oils. BMC Complement Altern Med 6: 39.

27. Bradesi P, Tomi F, Casanova J, Costa J, Bernardini AF (1997) Chemical composition of myrtleleaf essential oil from Corsica (France). J Essential Oil Res 9: 283-288.

28. Ozek T, Demirci B, Baser KHC (2000) Chemical composition of Turkish myrtle oil. J Essential Oil Res 12: 541-544.

29. Koukos PK, Papadopoulou KI, Papagiannopoulos AD, Patiaka D (2001) Chemicals from Greek forestry biomass: constituents of the leaf oil of Myrtus communis L. grownin Greece. J Essential Oil Res 13: 245-246.

30. Montazerozohori M, Zahedi S, Nasr-Esfahani M, Naghiha A (2014) Some new cadmium complexes: Antibacterial/antifungal activity and thermal behavior. J Indus Eng Chem 20: 2463-2470.

31. Prescott JF, Baggot JD, Walker RD (2000) Antimicrobial susceptibility testing and interpretation of results, in: Antimicrobial Therapy in Veterinary Medicine, Iowa State University Press, Ames, IA.

32. Raman N, Sakthivel A, Rajasekaran K (2007) Synthesis and spectral characterization of antifungal sensitive Schiff base transition metal complexes. Mycobiol 35: 150-153.

33. Liu YT, Lian GD, Yin DW, Su BJ (2013) Synthesis, characterization and biological activity of ferrocene-based Schiff base ligands and their metal (II) complexes. Spectrochimica Acta Part A: Mol Biomol Spectro 100: 131-137. 